$A N L / C M B / P P-88274 \quad 88274$

\author{
JUI 291997 \\ OSTI
}

\title{
Chaperonin polymers in archaea: \\ The cytoskeleton of prokaryotes? \\ DISCLAIMER
}

\begin{abstract}
This report was prepared as an account of work sponsored by an agency of the United States Government. Neither the United States Government nor any agency thereof, nor any of their employees, makes any warranty, express or implied, or assumes any legal liability or responsibility for the accuracy, completeness, or usefulness of any information, apparatus, product, or process disclosed, or represents that its use would not infringe privately owned rights. Reference herein to any specific commercial product, process, or service by trade name, trademark, manufacturer, or otherwise does not necessarily constitute or imply its endorsement, recommendation, or favoring by the United States Government or any agency thereof. The views and opinions of authors expressed herein do not necessarily state or reflect those of the United States Government or any agency thereof.
\end{abstract}

Jonathan D. Trent*, Hiromi K. Kagawa, and Nestor J. Zaluzec ${ }^{+}$

Center for Mechanistic Biology and Biotechnology

+Materials Science Division

Argonne National Laboratory

9700 S. Cass Avenue

Argonne, Illinois 60439

*Corresponding author:

tel: $708 \quad 252-3917$

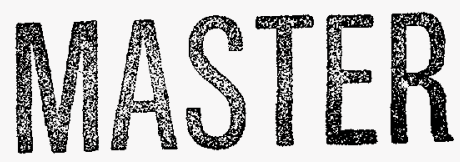

fax: $708 \quad 252-9937$

email: Trent@ANLCMB.bim.anl.gov

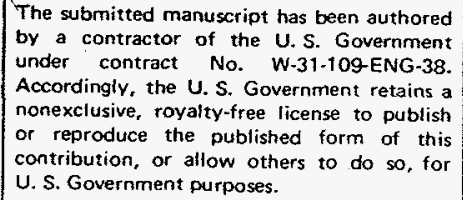




\section{DISCLAIMER}

Portions of this document may be illegible in electronic image products. Images are produced from the best available original document. 
Chaperonins are protein complexes that play a critical role in folding nascent polypeptides under normal conditions and refolding damaged proteins under stress conditions ${ }^{1-4}$. In all organisms these complexes are composed of evolutionarily conserved $60-\mathrm{kDa}$ proteins arranged in double-ring structures with between 7 and 9 protein subunits per ring $5-7$. These double ring structures are assumed to be the functional units in vivo $1,8,9$, although they have never been observed inside cells. Here we show that the purified chaperonin from the hyperthermophilic archaeon Sulfolobus shibatae, which is closely related to chaperonins in eukaryotes $10-12$, has a double ring structure at low concentrations $(0.1 \mathrm{mg} / \mathrm{ml})$, but at more physiological concentrations, the rings stack end to end to form polymers. The polymers are stable at physiological temperatures $\left(75{ }^{\circ} \mathrm{C}\right)$ and closely resemble structures observed inside unfixed $S$. shibatae cells. We suggest that in vivo chaperonin activity may be regulated by polymerization and that chaperonin polymers may act as a cytoskeleton-like structure in archaea and bacteria.

The $S$. shibatae chaperonin, known as the rosettasome ${ }^{12}$, was purified at room temperature by chromatography and density gradient centrifugation and analyzed by transmission electron microscopy (TEM) (Fig. 1). At a concentration of $0.1 \mathrm{mg} / \mathrm{ml}$ the rosettasomes had a typical double-ring appearance ${ }^{10}$ (Fig. 1A). At $0.5 \mathrm{mg} / \mathrm{ml}$, however, many of the double rings were stacked, primarily end to end, to form short polymers (Fig. 1B), and at 1.0 $\mathrm{mg} / \mathrm{ml}$ these polymers were longer and frequently aligned side by side to form bundles (Fig 1C). The polymers required $\mathrm{Mg}^{++}$, indicated by their absence in $1.0 \mathrm{mg} / \mathrm{ml}$ samples that lacked $\mathrm{MgCl}_{2}$ and $\mathrm{KCl}$ (Fig. 1D), their continued absence when $\mathrm{KCl}$ was added to these samples (Fig. 1E), and their reappearance when $\mathrm{MgCl}_{2}$ was added (Fig. 1F). To determine if these polymers were stable at physiological temperatures for $S$. shibatae, which normally lives in geothermal hot springs 13 , we exposed them to $75{ }^{\circ} \mathrm{C}$ for up to $3 \mathrm{~h}$. The network of 
branched polymers was stable at this temperature and micrographs were indistinguishable from those taken at room temperature (Fig. 2). This stability at physiological temperatures suggests that these polymers may exist in vivo.

It is known that the constituent proteins of the rosettasome ( $\alpha$ and $\beta$ subunits) are among the most abundant proteins in $S$. shibatae 12, 13. To determine if their intracellular concentrations are conducive to polymer formation, we compared measured amounts of pure proteins with extracts from specific numbers of cells (Fig. 3) and used measurements from scanning electron micrographs of whole cells $(n=100)$ to determine cell volumes. We thereby calculated an intracellular rosettasome concentration of 24 to 28 $\mathrm{mg} / \mathrm{ml}$, depending on the method used for protein separation (see caption Fig. 3). Since $\mathrm{Mg}^{++}$is also required for polymer formation, we determined its concentration in cells using inductive coupled plasma-atomic emission spectrometry (ICP-AES). We measured 1.03 $\mathrm{mg} \mathrm{Mg}^{++} / \mathrm{g}$ (cell dry weight), which corresponds to a concentration of $12.9 \mathrm{mM}$ (assuming dry weight equals $30 \%$ wet weight and $1 \mathrm{~g}$ wet weight $=1 \mathrm{ml}$ cell vol). The intracellular concentrations of both rosettasomes and $\mathrm{Mg}^{++}$are conducive to polymer formation and polymers should therefore exist inside cells unless there are specific intracellular factors preventing their formation.

We looked for polymers in $S$. shibatae cells by TEM after removing their protein surface layer (S-layer) with detergent 14, 15 and staining them with uranyl acetate. We found structures remarkably similar to the in vitro polymers in many cells (e.g. Fig. 4 A-F). These intracellular polymers do not resemble known structures in $S$. shibatae, such as S-layer arrays $15-17$ or chromatin 18-20, and while they do resemble actin and tubulin filaments 21 , neither of these eukaryotic cytoskeletal proteins is present in $S$. shibatae. The average width of the intracellular polymers, $11 \pm 1 \mathrm{~nm}$, was nearly identical to that of the in vitro polymers, $10.7 \pm 0.6$, and both have a distinctive and similar periodic structure. Fourier analyses of this structure revealed periodicities of approx. 12, 7, and $5 \mathrm{~nm}$ in the intracellular polymers and 10, 8, 5, and $4 \mathrm{~nm}$ in the in vitro polymers. These periodicities are not 
significantly different and can be attributed to features of the rosettasomes themselves or their orientation in the polymers. The similarity between the in vitro and in vivo polymers is evident in the direct comparison shown in Figure 4G. Therefore, as expected from the intracellular concentrations of rosettasome and $\mathrm{Mg}^{++}$, we conclude that the archaeal chaperonin is polymeric in vivo.

This conclusion has important consequences for understanding rosettasome function and perhaps chaperonin function in general. If we maintain that the double ring is the functional chaperonin unit as is now believed 8,9 , and the end of the rings and central cavities are the sites for recognition and binding of unfolded proteins $1,2,7$, then polymerization may block these functional sites. Cells could then regulate chaperonin activity by regulating polymerization and chaperonin activity could therefore be changed, during heat shock for example, without de novo protein synthesis 22 . Alternatively, if the chaperonin double rings are primarily the building blocks for polymers, and the polymers themselves are the functional units, then the role of the double rings in heat shock 8,23 and protein folding 24 may be quite different than previously thought. The polymers and polymer bundles may be the "chaperones" for protein folding and assembly by actively binding or passively sequestering folding intermediates of proteins. Hypothesizing such a cytoskeleton-like function for chaperonin polymers predicts possible interactions with other ring structures, such as the proteosome 25 , other heat shock protein polymers, such as $\mathrm{Hsp} 70^{26}$, or other macromolecule such as RNA $27,28$.

While it is generally believed that prokaryotes lack a cytoskeleton, it has been argued that archaea must have some kind of cytoskeleton based on their morphology, their resistance to osmotic shock, and the gelling properties of their cytoplasm, although cytoskeletal proteins have not been identified 29,30 . The abundance of chaperonins in archaea (4\% of total protein in $S$. shibatae, higher in other species $\left.^{31}\right)$ and in bacteria $\left(1-7 \%\right.$ of total protein $\left.{ }^{32}\right)$ is comparable to that of the major cytoskeletal proteins (tubulin and actin) in eukaryotes. We have demonstrated that an archaeal chaperonin forms polymers in vitro and that similar polymers are 
present in vivo. Others have demonstrated that the bacterial chaperonin (GroEL), in conjunction with its co-chaperonin (GroES), also forms polymers in vitro 33 and that protein polymers are present in some bacteria that are immunologically cross reactive with antibodies against GroEL 34,35 . In addition, the archaeal chaperonins share nearly $40 \%$ amino acid sequence identity with a family of eukaryotic proteins known as TCP1's 10, 12, 36 that interact with tubulin and actin in vitro 37,5 and are essential for the normal development and function of the cytoskeleton in vivo $38-40$. These different lines of evidence support the hypothesis that chaperonins may have a cytoskeletal function in prokaryotes. In general, our findings provide a new perspective on the role of chaperonins in vivo.

\section{References}

1. Martin, J., Mayhew, M., Langer, T. \& Hartl, F.-U. Nature 366, 228-233 (1993).

2. Frydman, J. \& Hartl, F.-U. in The Biology of Heat Shock Proteins and Molecular Chaperones (eds. Morimoto, R.I., Tissiéres, A. Georgopoulos, C.) 251-283 (Cold Spring Harbor Laboratory Press, Plainview, 1994).

3. Parsell, D.A. \& Lindquist, S. in The Biology of Heat Shock Proteins and Molecular Chaperones (eds. Morimoto, R.I., Tissiéres, A. \& Georgopoulos, C.) 457-494 (Cold Spring Harbor Laboratory Press, Plainview, 1994).

4. Ranson, N.A., Dunster, N.J., Burston, S.G. \& Clarke, A.R. J. Mol. Biol. 250, 581-586 (1995).

5. Gao, Y., Thomas, J.O., Chow, R.L., Lee, G.-H. \& Cowan, N.J. Cell 69, 1043-1050 (1992).

6. Marco, S., et al. FEBS Letters 341, 152-155 (1994).

7. Chen, S., et al. Nature 371, 261-264 (1994).

8. Hendrick, J.P. \& Hartl, F.-U. Annu. Rev. Biochem. 69, 349-384 (1993).

9. Lorimer, G.H. Structure 2, 1125-1128 (1994). 
10. Trent, J.D., Nimmesgern, E., Wall, J.S., Hartl, F.-U. \& Horwich, A.L. Nature 354, 490-493 (1991).

11. Kubota, H., Hynes, G. \& Willison, K. Eur. J. Biochem. 230, 3-16 (1995).

12. Kagawa, H.K., et al. J. Mol. Biol. 253, $712-725$ (1995).

13. Trent, J.D., Osipiuk, J. \& Pinkau, T. J. Bac. 172, 1478-1484 (1990).

14. Taylor, K.A., Deatherage, F.J. \& Amos, L.A. Nature 299, 840-842 (1982).

15. Baumeister, W. \& Lembcke, G. J. Bioenerg. Biomemb. 24, 567575 (1992).

16. Kandler, O. \& König, H. in The Biochemistry of Archaea (Archaebacteria) (eds. Kates, M., Kushner, D.J. \& Matheson, A.T.) 223260 (Elsevier Science Publishers B.V., Amsterdam, 1993).

17. Prüschenk, R. \& Baumeister, W. Eur. J. Cell Biol. 45, 185-191 (1987).

18. Bohrmann, B., Arnold-Schulz-Gahmen, B. \& Kellenberger, E. $J$. Struct. Biol. 104, 112-119 (1990).

19. Shioda, M., Sugimori, K., Shiroya, T. \& Takanagi, S. J. Bac. 171, 4515-4517 (1989).

20. Shioda, M., Shiroya, T. \& Takanagi, S. Mol. Genet. 8, 163-166 (1989).

21. Gregorio, C.C., Weber, A., Bondad, M., Pennise, C.R. \& Fowler, V.M. Nature 377, 83-86 (1995).

22. Welch, W.J. \& Suhan, J.P. J. Cell Biol. 101, 1198-1210 (1985).

23. Georgopoulos, C. \& Welch, W.J. Annu. Rev. Cell Biol. 9, 601-634 (1993).

24. Ellis, R.J., Laskey, R.A. \& Lorimer, G.H. Molecular Chaperones 1121 (Chapman and Hall, London, 1993).

25. Kessel, M., et al. J. Mol. Biol. 250, 587-594 (1995).

26. King, C., Eisenberg, E. \& Greene, L. J. Biol. Chem. 270, 2253522540 (1995).

27. Georgellis, D., Sohlberg, B., Hartl, F.U. \& Gabain, A.v. Mol. Microbiol. 16, 1259-1268 (1995).

28. Herschlag, D. J. Biol. Chem. 270, 20871-20874 (1995).

29. Searcy, D.G. \& Hixon, W.G. BioSystems 25, 1-11 (1991). 
30. Hixon, W.G. \& Searcy, D.G. BioSystems 29, 151-160 (1993).

31. Phipps, B.M., Hoffmann, A., Stetter, K.O. \& Baumeister, W. EMBO J. 10, 1711-1722 (1991).

32. Herendeen, S.L., VanBogelen, R.A. \& Neidhardt, F.C. J. Bac. 139, 185-194 (1979).

33. Harris, J.R., Plückthun, A. \& Zahn, R. J. Struct. Biol. 112, 216230 (1994).

34. Bermudes, D., Hinkle, G. \& Margulis, L. Microbiol. Rev. 58, 387 400 (1994).

35. Munson, D. Obar, R., Tzertzinis, G. Margulis, L. BioSystems 31, 161-167 (1993).

36. Waldmann, T., et al. Eur. J. Biochem. 227, 848-856. (1995).

37. Yaffe, M.B., et al. Nature 358, 245-248 (1992).

38. Ursic, D. \& Culbertson, M.R. Mol. Cell. Biol. 11, 2629-2640 (1991).

39. Ursic, D., Sedbrook, J.C., Himmel, K.L. \& Culbertson, M.R. Mol. Biol. Cell 5, 1065-1080 (1994).

40. Creutz, C.E., Liou, A., Snyder, S.L., Brownawell, A. \& Willison, K. J. Biol. Chem. 269, 32035-32038 (1995).

41. Rasband, W. S. \& Bright, D. S. Microbeam Anal. 4, 137-149 (1995).

42. Reeves, A. A. Thesis: Masters of Science. Thayer School of Engineering, Dartmouth College, Hanover, New Hampshire, USA. (1990)

\section{Acknowledgments}

We thank S. Tollaksen, C. Giometti for technical assistance, F. Stevens, M. Donnelly, D. Nadziejka, M. Ellis, and S. Johansen Trent for editorial comments and DOE for financial support. 


\section{Figure Captions}

Fig. 1: The Sulfolobus shibatae chaperonin (rosettasome) polymerizes at higher concentrations in the presence of $\mathrm{Mg}^{++}$. In a buffer containing $20 \mathrm{mM}$ HEPES ( $\mathrm{pH} 7.5$ ), $10 \mathrm{mM} \mathrm{KCl}$, and $10 \mathrm{mM}$ $\mathrm{MgCl}_{2}$ (HKM buffer) double rings predominate at rosettasome concentrations of $0.1 \mathrm{mg} / \mathrm{ml}$ (A); rings and short chains were seen at $0.5 \mathrm{mg} / \mathrm{ml} \mathrm{(B);} \mathrm{and} \mathrm{long} \mathrm{chains} \mathrm{and} \mathrm{bundles} \mathrm{of} \mathrm{polymers} \mathrm{were}$ present at $1.0 \mathrm{mg} / \mathrm{ml}$ (C). Chains and polymers did not form in 4.7 mM HEPES ( $\mathrm{pH} 7.5$ ) containing $24 \mu \mathrm{M}$ EDTA \& DTT (D); or when 10 $\mathrm{mM} \mathrm{KCl}$ was added (E); but did form when $10 \mathrm{mM} \mathrm{MgCl} 2$ was added (F).

Method: Rosettasomes were purified from $S$. shibatae cells grown at $75{ }^{\circ} \mathrm{C}$ in standard yeast extract medium 13 . Cells were opened by sonication in the presence of three volumes HKM buffer, extracts were treated with DNase at room temp. for $30 \mathrm{~min}$ and then centrifuged at $30,000 \mathrm{rpm}$ for $30 \mathrm{~min}$ in $50.2 \mathrm{Ti}$ rotor (Beckmann). The supernatant was applied to a DEAE-sepharose column equilibrated in HKM buffer and proteins were eluted in a 0 to $1 \mathrm{M}$ $\mathrm{NaCl}$ gradient. Rosettasome containing fractions were determined by SDS-PAGE 10 and further purified by Mono-Q (Pharmacia). Protein concentration was determined by DC Protein Assay system (BioRad) using BSA as a standard. Different concentrations of freshly prepared protein samples (polymers nearly disappeared in samples stored at $4{ }^{\circ} \mathrm{C}$ for 1 week) were attached to lacy carbon grids with ultra thin formvar (Ladd Scientific), stained with $2 \%$ uranyl acetate for $3 \mathrm{~min}$, air dried, and viewed in a Philips EM420T or CM30T with LAB6 filaments at 80 to $300 \mathrm{kV}$. No changes in the microstructure of samples was observed at the working resolution with electron doses of $\sim 1$ to 200 electrons $/ \AA^{2}$. Micrographs were taken within this dose range at defocuses of -200 to $-800 \mathrm{~nm}$ with illuminationconvergence angles of $\sim 1 \mathrm{mR}$ and scattering angle of $5 \mathrm{mR}$ using a room temperature, double tilt, berylium stage. Micrographs were digitized using a flat bed, 10 bit, 1200 DPI scanner (Powerlook Pro, 
UMAX) and data processing was done on Macintosh work stations with the programs NIH Image 41 and Adobe Photo Shop.

Fig. 2: Comparison of the network of polymers at room temperatures and after a $3 \mathrm{~h}$ exposures to $75{ }^{\circ} \mathrm{C}$ (insert). In both heat treated and control samples bundles of polymers were present, consisting of double rings primarily stacked end to end (side views) and with some rings (end views) also visible.

Method: Rosettasome samples at $2 \mathrm{mg} / \mathrm{ml}$ were polymerized at room temperature in HKM buffer and exposed to $75{ }^{\circ} \mathrm{C}$ for $0,1,2$, and $3 \mathrm{~h}$ in a programmable heating block (Hybaid, OmniGene). Samples removed from the heating block were immediately processed for TEM as described (Fig 1).

Fig. 3: Abundance of rosettasome in $S$. shibatae cells. The Coomassie-stained protein bands from 1.0 to $2.6 \mu \mathrm{g}$ of rosettasome (Pure protein), total proteins from 1 to $4 \times 10^{8}$ cells (Cell extracts), and from a molecular mass standard $(\mathrm{kDa})$ on a denaturing (SDS) polyacrylamide gel. The plot of the stained bands (area $\mathrm{x}$ intensity) vs known amounts of pure protein was used to calculate the amount of rosettasome in cells (insert).

Method: The concentration of $S$. shibatae cells in an actively growing culture was determined by direct counts on a haemocytometer (Neubauer). Volumes containing specific numbers of cells centrifuged at 10,000 RPM room temp. for 3 min (Hermle microfuge) and cell pellets were lysed by the addition of SDS-buffer (final conc. $10 \%$ glycerol, 5\% B-mercaptoethanol, 3\% SDS, $65 \mathrm{mM}$ Tris$\mathrm{HCl} \mathrm{pH} 6.8,0.001 \%$ bromophenol blue). Extracts from different numbers of cells and samples containing varying amounts of pure rosettasome (see caption Fig. 1) were applied to a $10 \%$ denaturing polyacrylamide gel and proteins were separated by electrophoresis. After staining with Coomassie brilliant blue (R280), gels were scanned (Powerlook Pro scanner, UMAX) and the digitized areas and intensities of stain associated with rosettasome bands was determined. The linear plot derived from varying amounts of pure proteins was used to estimate the absolute amount of rosettasome in 
cells. Concentrations were determined by correcting for cell volumes, which were calculated using the formula for a sphere and cell diameters measured from electron micrographs $(n=100)$. The rosettasome concentration of $24.4 \mathrm{mg} / \mathrm{ml}$ obtained using this procedure was corroborated $(27.9 \mathrm{mg} / \mathrm{ml})$ by two dimensional gel electrophoresis (data not shown).

Fig. 4: Transmission electron micrographs of unfixed $S$. shibatae cells with their protein surface layer removed. Whole cells (A, C, E) and magnified regions (B, D, F) show polymer structures (arrowheads). Comparison of in vitro and in vivo polymers $(\mathrm{G})$.

Methods: Cells $(1 \mathrm{ml})$ in mid-log phase growth at $75{ }^{\circ} \mathrm{C}$ were removed from medium by centrifugation $(30 \mathrm{sec} .12,000 \mathrm{rpm}$, table top centrifuge), washed and resuspended in $50 \mu 1$ HKM buffer (Fig.1). Samples $(8 \mu 1)$ were placed on formvar lacy grids (Ladd Scientific) and $2 \mu 1$ of $10 \%$ triton X100 was added. Triton X100 was removed by repeatedly washing in HKM buffer before a DNase (final. conc. 0.1 unit $/ \mu 1$, Promega) treatment for $10 \mathrm{~min}$. Grids were washed again in HKM buffer, stained for $3 \mathrm{~min}$ in $2 \%$ uranyl acetate, and air dried. All solutions were $0.22 \mu \mathrm{m}$ filtered. Transmission electron micrographs were done as described in Fig. 1. Fourier analysis was done on digitized images using the FFT implementation in NIH Image 42 and all dimensions are given for center to center measurements of specific features. 

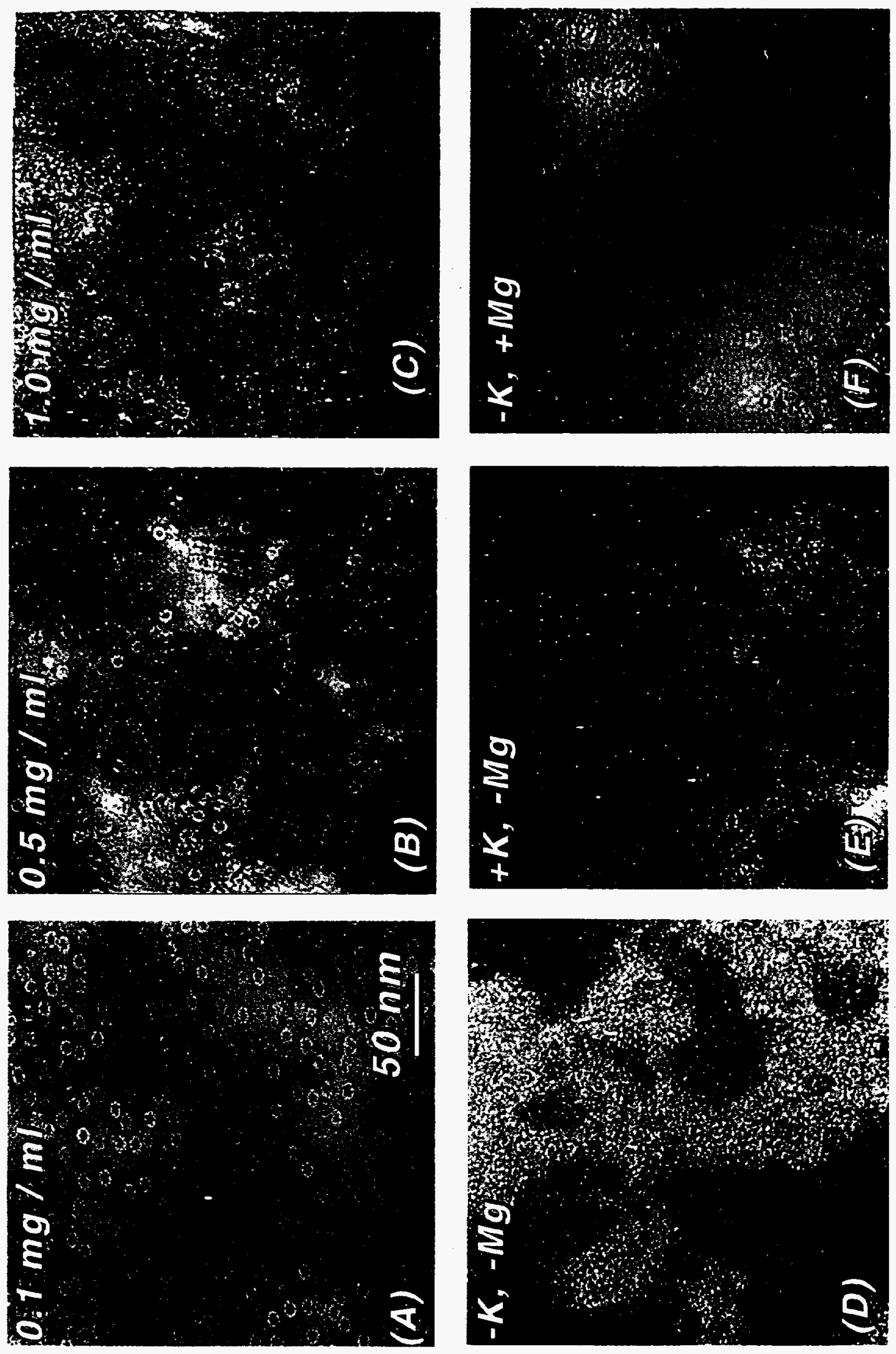


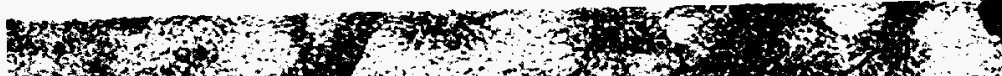

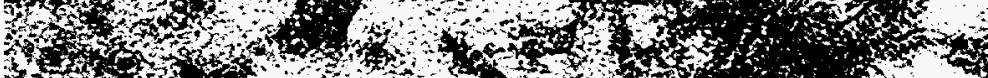

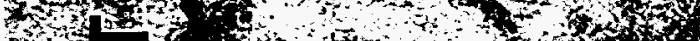

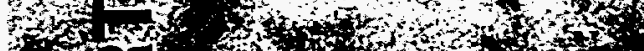

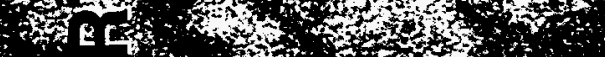

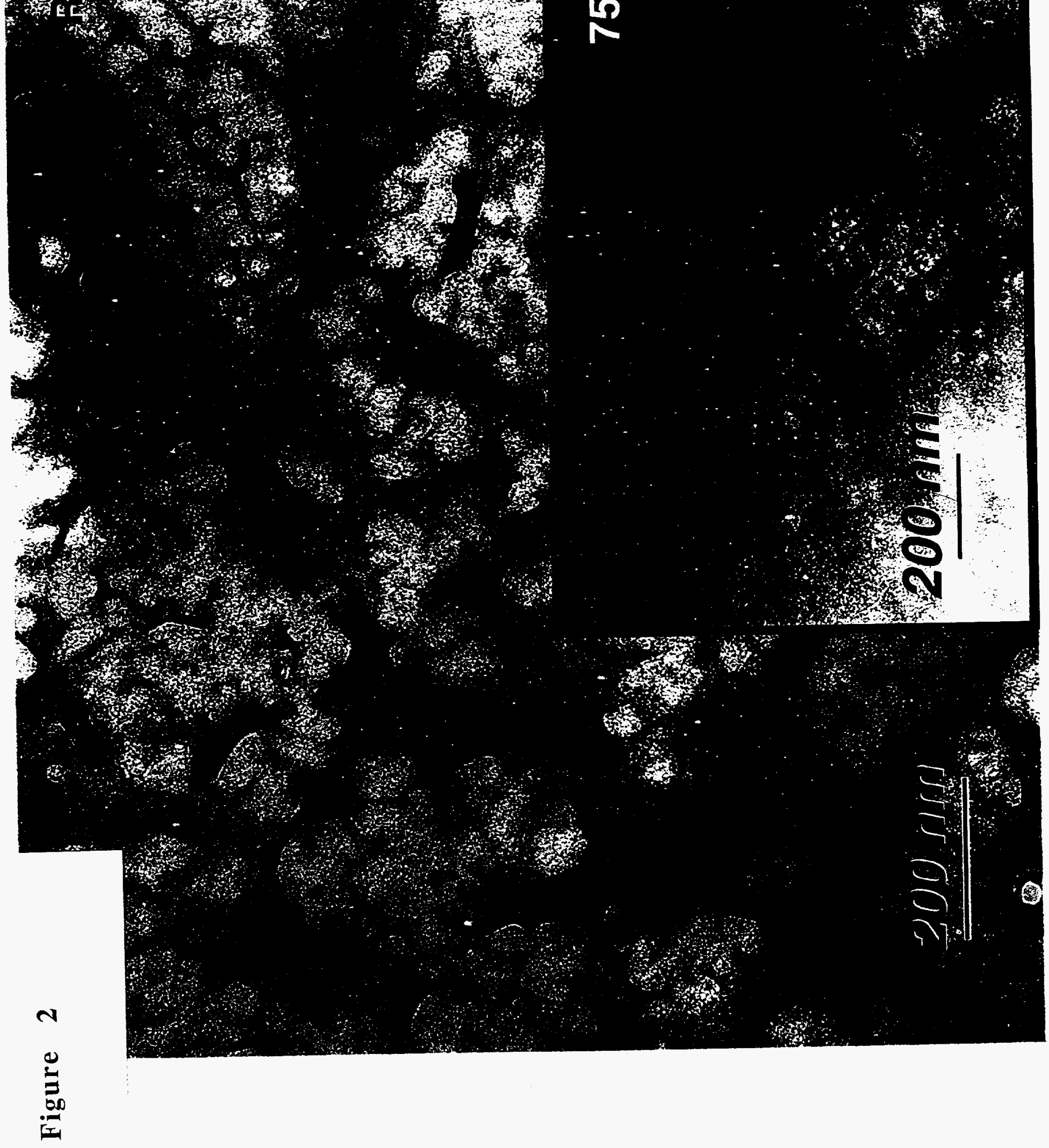




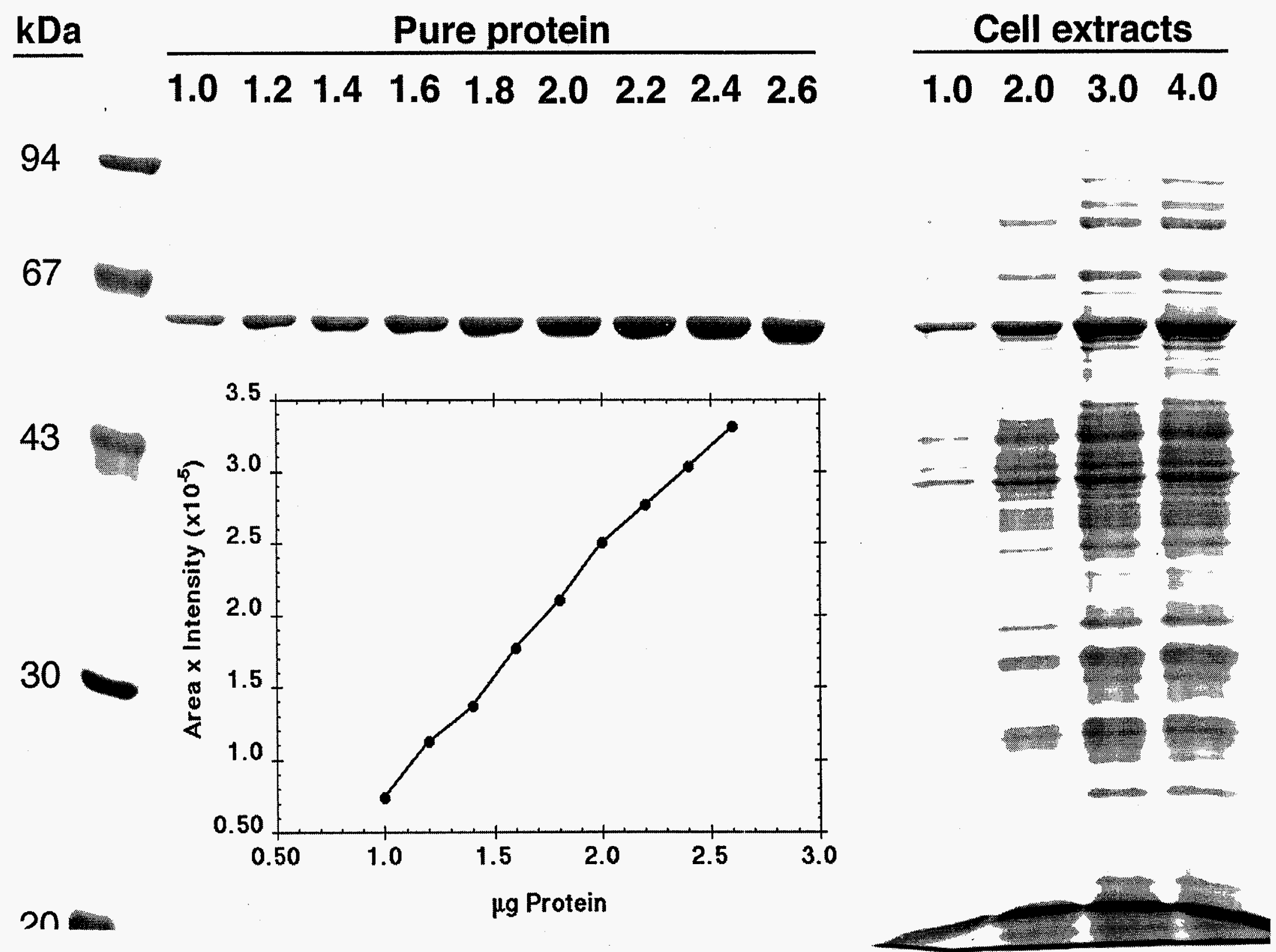

Figure 3 


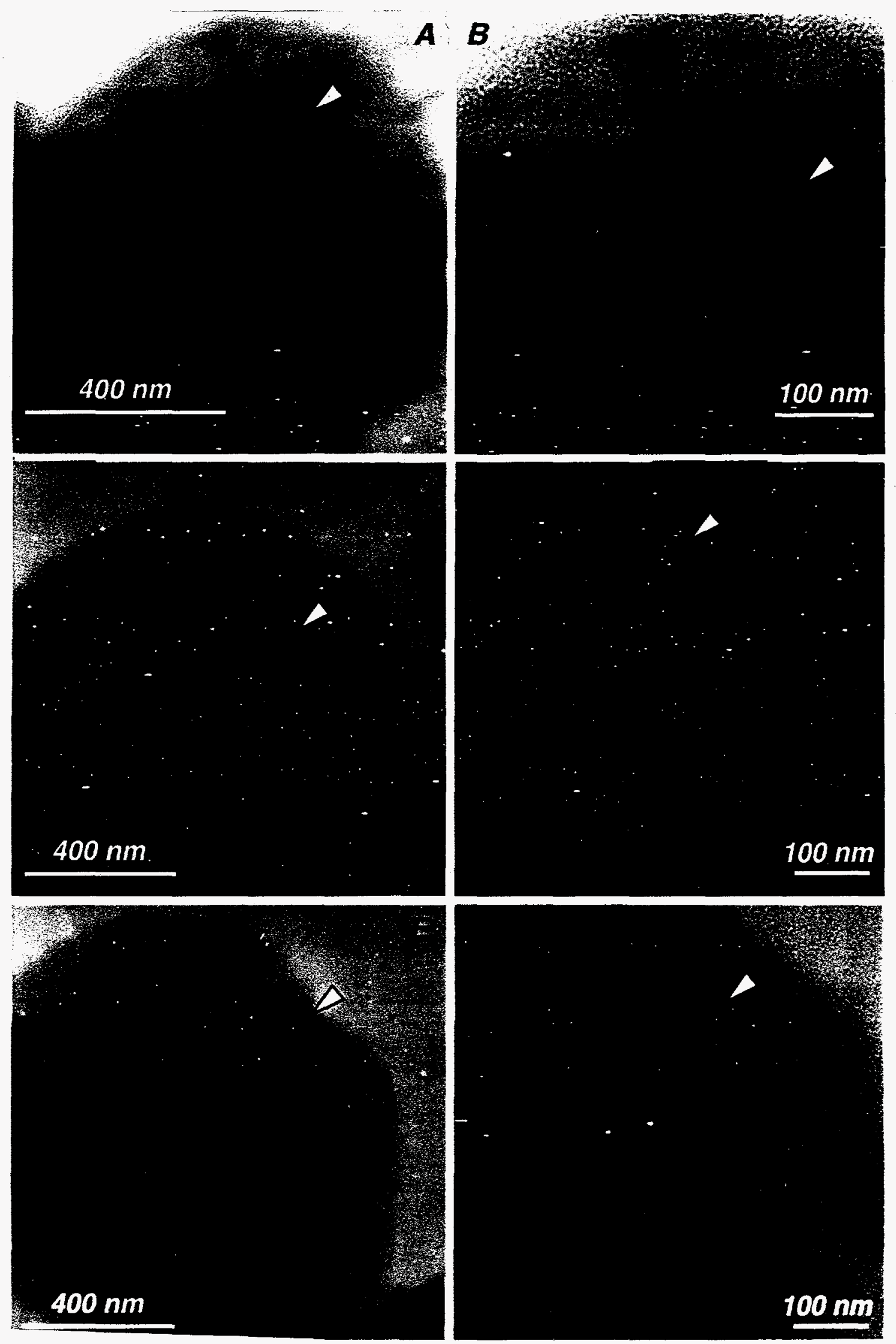

Figure 4 

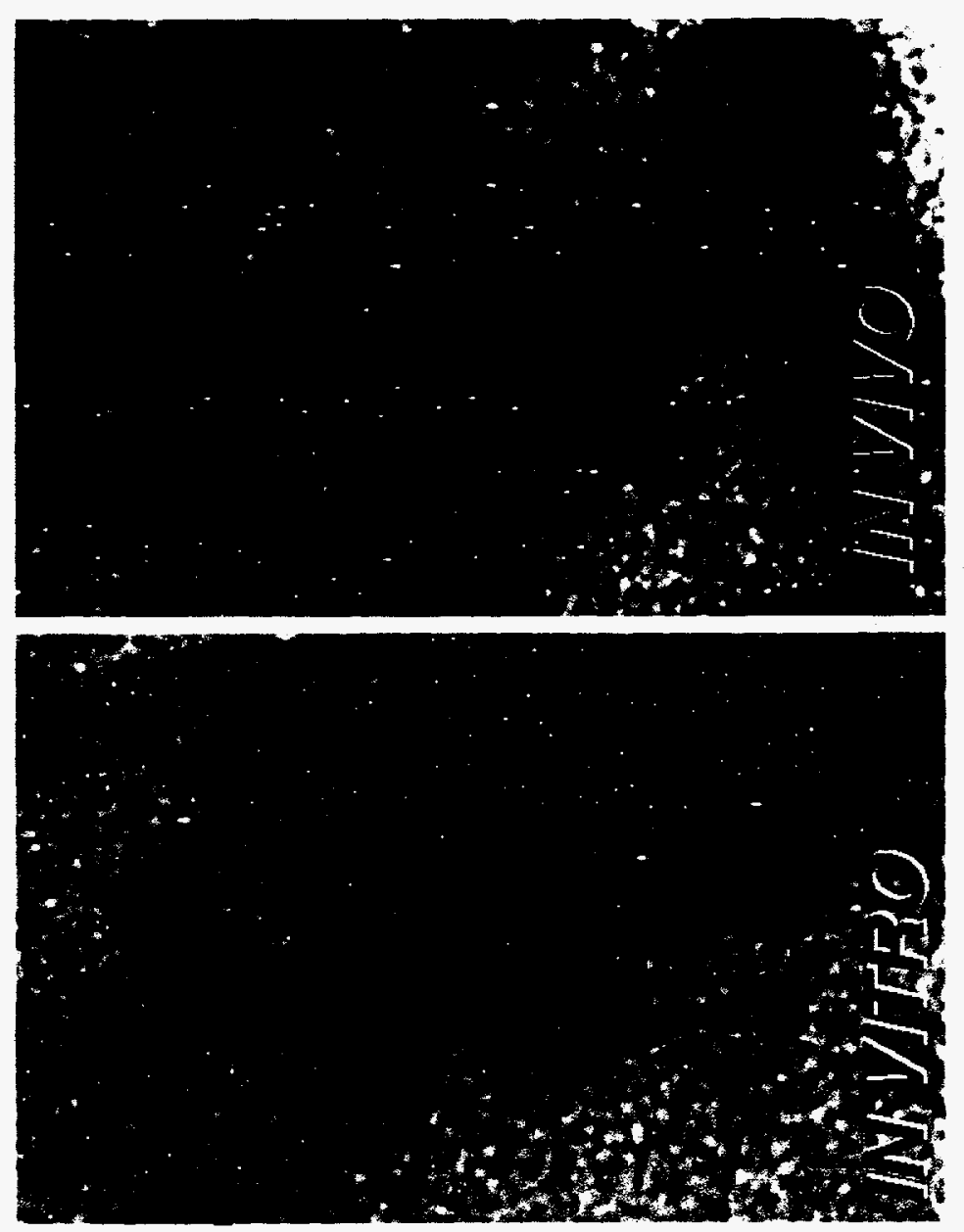